\title{
Characterization and delineation of two infraspecific taxa of Dioscorea esculenta (Lour.) Burkill: The leaf architecture approach
}

\author{
MENISA A. ANTONIO ${ }^{1,2, \boldsymbol{\nu}}$, INOCENCIO E. BUOT JR. ${ }^{2}$ \\ ${ }^{1}$ Research Directorate, Mariano Marcos State University. City of Batac. Ilocos Norte, 2906, Philippines \\ `email: maantonio2@up.edu.ph \\ ${ }^{2}$ Plant Biology Division, Institute of Biological Sciences, University of the Philippines Los Baños. College, Batong Malake, Los Baños, Laguna 4031, \\ Philippines
}

Manuscript received: 23 December 2020. Revision accepted: 17 March 2021

\begin{abstract}
Antonio MA, Buot Jr. IE. 2021. Characterization and delineation of two infraspecific taxa of Dioscorea esculenta (Lour.) Burkill: The leaf architecture approach. Biodiversitas 22: 1783-1789. The current taxonomic treatment for the wild and cultivated species of Dioscorea esculenta Lour. (Burkill) presented them as two different varieties. However, there are confusions among botanists and farmers. So, leaf architecture analysis was done to investigate whether leaf architecture data would support their current taxonomic treatment. The varieties showed variability in several characteristics indicating their distinct identity from each other. Based on general leaf characters, they differ in all the parameters observed. But on venation characters, evident variation was seen only on the number of basal veins and secondary vein angle of divergence. Nevertheless, the two varieties resemble each other in a number of characters, i.e. campylodromous primary veins, brochidodromous secondary veins, presence of intermarginal and intersecondary veins, admedially ramified tertiary veins, and well-developed areolation. Dendrogram generated from cluster analysis agrees with and supports above leaf architectural examination, suggesting the two varieties to be recognized as separate taxa. But the current taxonomic treatment naming them as var. spinosa and var. fasciculata seemed to have dragged the cultivated plant into the classification system generally used for wild plants. Thus, the proposed name for the cultivated plant is D. esculenta 'fasciculata' while that of the wild plant remains as $D$. esculenta var. spinosa.
\end{abstract}

Keywords: Dioscorea esculenta var. spinosa, Dioscorea esculenta var. fasciculata, leaf anatomy, leaf morphology, venation patterns

\section{INTRODUCTION}

Dioscorea $\mathrm{L}$. is a genus of more than 600 species of herbaceous or viny plants in the family Dioscoreaceae. The genus had been expanded with the recent circumscription subsuming the monotypic genera Borderea, Epipetrum, Rajania, Nanarapenta, Tamus, etc. following the phylogenetic analysis done by Caddick et al. (2002). Morphological diversity, which is partly attributed to the plants' wide geographic distribution, is reported in the genus. Such diversity, including the various local names used for them (Prain and Burkill 1913) triggered difficulties in identification. Thus, names and nomenclatural errors proliferated in the genus ( $R a z$ 2016).

There are 17 Dioscorea species which are reported in the Philippines (Pelser et al 2011). Except for the cultivated Dioscorea alata L. (greater yam, or ubi), Dioscorea esculenta (Lour.) Burkill (lesser yam or tugui) and Dioscorea bulbifera (aerial yam or ubi-bunga), the rest of the species grow in the wild.

Pelser et al. (2011) listed two varieties of D. esculenta: namely var. fasciculata (Roxb.) Prain and Burkill as the entirely cultivated plants devoid of thorny roots, and var. spinosa (Prain) R. Knuth as the cultigen and wild plants well-provided with thorny roots. Current taxonomic treatment, generally based on genetic status (cultivated vs. wild) and tuber morphology, seemed confusing to the botanists and farmers and the production sector. Antonio ( 2008) characterized the wild and cultivated varieties in terms of morphology. The varieties were observed similar in several leaf, stem and inflorescence characteristics but differ in terms of the spines on the anchor roots, tuber size and shape, and stolon length. Since plant morphology exhibits phenotypic plasticity, there is a need to supplement morphological data with more stable characters. In 2001, Roth-Nebelsick et al. (2001) hypothesized that leaf venation patterns such as anastomoses are genetically fixed. Since then, leaf architecture approach has gained importance and utilization in a range of applications such as in systematic botany. Among the studies on the application of leaf architecture techniques include characterization and species delineation in the genera Psychotria (Banaticla and Buot 2004) and Hoya (Salvaña and Buot 2014; Villareal and Buot 2015; Jumawan and Buot 2016; Torrefiel and Buot 2017; Tan and Buot 2018; Baltazar and Buot 2019), and families Malvaceae (Laraño and Buot 2010), Combretaceae (Baroga and Buot 2004) and Cucurbitaceae (Rao and Rao 2015).

This taxonomic investigation using leaf architecture approach was done in relation to the wild and cultivated $D$. esculenta and D. alata (outgroup) to determine whether leaf architecture data will support the current taxonomic treatment given to the two varieties of D. esculenta plants. 


\section{MATERIALS AND METHODS}

Thirty leaf samples each of cultivated and wild $D$. esculenta, and D. alata (outgroup) were randomly collected from planted accessions at the field genebank of the Mariano Marcos State University, City of Batac, Ilocos Norte, Philippines (Figure 1). The collected leaf samples were pressed and oven-dried. Samples were examined using a dissecting microscope. Their leaf architecture was described following the leaf architecture characters and terminologies of Hickey (1973) and the Leaf Architecture Working Group (1999). Length and width were measured using ruler while angles of divergence were measured using a protractor. The studied leaf samples were deposited at the Plant Biology Division Herbarium (PBDH) at the Institute of Biological Sciences, University of the Philippines Los Baños, College, Laguna, Philippines.

A dichotomous key to the three taxa was constructed using leaf architecture characters. Cluster analysis was also conducted using PAST ver. 3.23 (Hammer et al. 2019) to determine and estimate the genetic relationship of the two varieties of $D$. esculenta, together with the outgroup $D$. alata. Twenty-eight leaf characters were used, and data were transformed into a scale of 1 to 3 depending on the values or data obtained. Dendrograms were constructed using unweighted pair-group average (UPGMA) as the algorithm, and Euclidean distance as the similarity index.

\section{RESULTS AND DISCUSSION}

General morphology of Dioscorea esculenta var. spinosa and D. esculenta var. fasciculata

In aid of presenting the distinct identity of the two varieties of $D$. esculenta, an understanding of their general morphology is deemed necessary. Both taxa shared characters such as left-twining habit, spiny stem and leaf petiole, cordate and pubescent leaves, spike inflorescence (Figure 2) with flowers bearing six petals and six stamens, multiple tubers covered with roots throughout the surface, and uniform off-white tuber flesh. The wild plant $D$. esculenta var. spinosa, on the other hand, can be easily distinguished from the cultivated $D$. esculenta var. fasciculata by having numerous spines on the anchor roots, big and multiple tubers of varied shapes, and long stolons on which the tubers are suspended. Meanwhile, the cultivated D. esculenta var. fasciculata has sparse spines to nil in the anchor roots, and very short stolons, making the small tubers close to each other or clustered immediately at stem base (Table 1). Other distinguishing morphological features are observed in Table 1. While plant morphology is phenotypically plastic, these distinguishing characters still provide additional evidence delineating the two varieties.

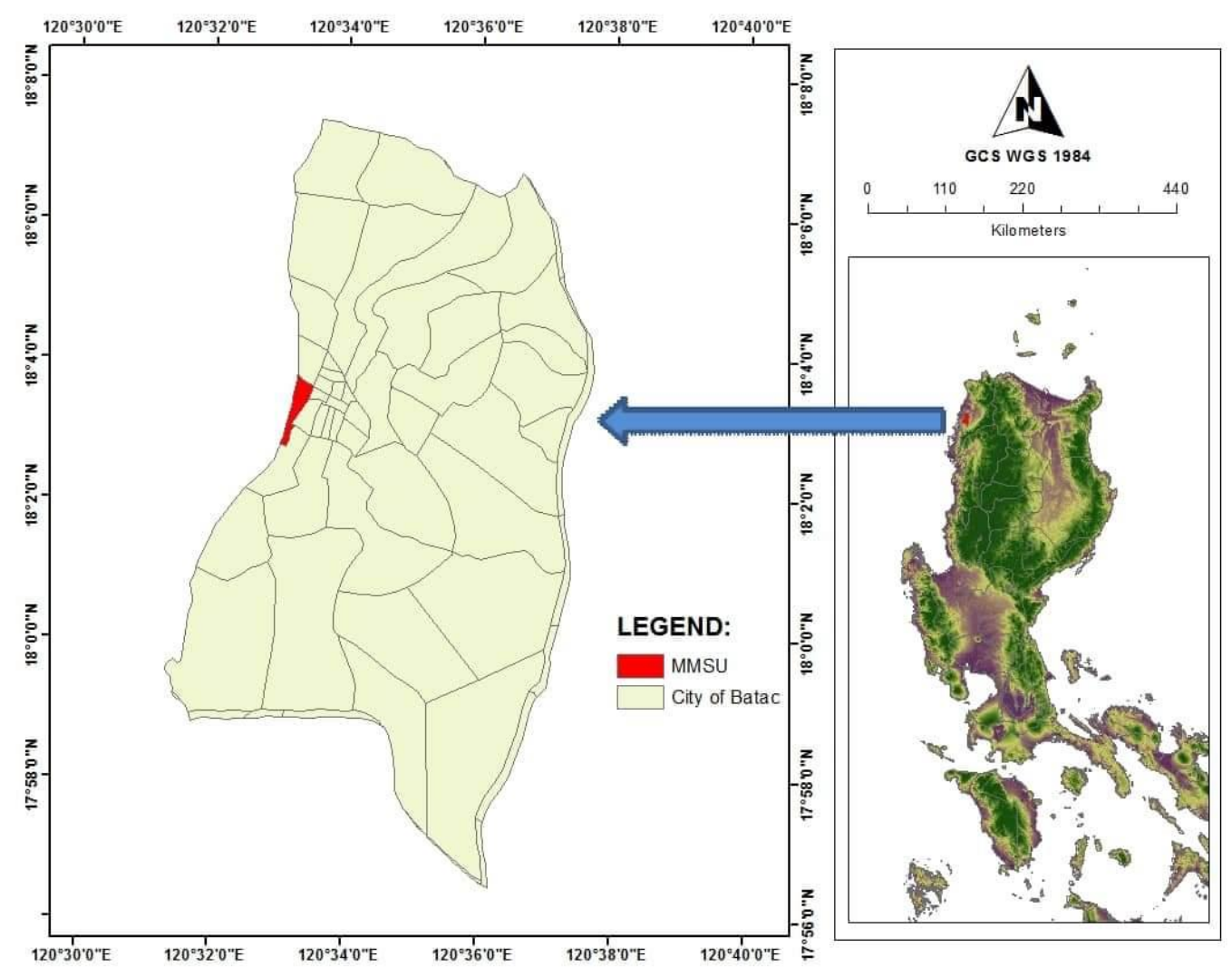

Figure 1. The City of Batac, which situates the MMSU field genebank, is located in the northwestern portion of the Philippines. The map was generated using ArcGIS v. 10.1 by Engr. RT Utrera, MMSU, City of Batac, Ilocos Norte. 


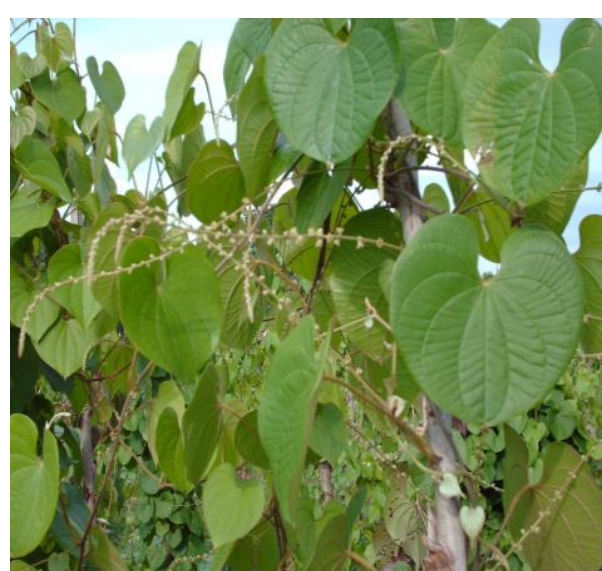

A

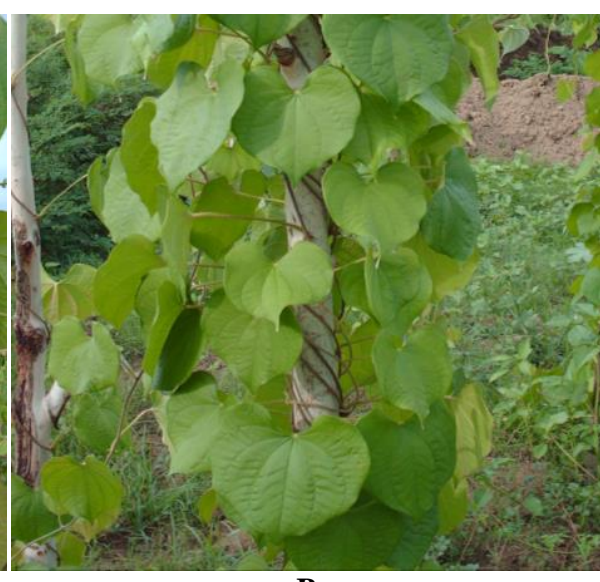

B

Figure 2. Leaf and inflorescence morphology of Dioscorea esculenta var. spinosa (A) and D. esculenta var. fasciculata (B). (Photo by M.A. Antonio)

Table 1. Distinguishing morphological characters of Dioscorea esculenta var. spinosa and D. esculenta var. fasciculata

\begin{tabular}{|c|c|c|}
\hline Character & $\begin{array}{l}\text { D. esculenta var. spinosa } \\
\text { Exsicc. Antonio } 6893 \text { (PBDH) }\end{array}$ & $\begin{array}{l}\text { D. esculenta var. fasciculata } \\
\text { Exsicc. Antonio } 6894 \text { (PBDH) }\end{array}$ \\
\hline Vine color & Purplish green as most dominant & Brownish green as most dominant \\
\hline Vine spines & Fewer spines at stem base, becoming denser up the stem & Dominant at stem base, diminishes up the stem \\
\hline Vine pubescence & Moderate & Slightly more than sparse \\
\hline Leaf lobe & No measurable distance between leaf lobes & $\begin{array}{l}\text { Distance between leaf lobes intermediate } \\
\text { (between narrow and distant) }\end{array}$ \\
\hline Petiole length & Shorter or of the same length as the blade & Longer or of the same length as the blade \\
\hline Petiole color & Dominantly brownish green & Dominantly all green \\
\hline Leaf density & High & sparse to intermediate \\
\hline Tuber size & $\begin{array}{l}\text { Big }(19.3 \mathrm{~cm} \text { long x } 10.1 \mathrm{~cm} \text { diameter) } \\
\text { (Biggest tuber harvested } 3.5 \mathrm{~kg} \text { ) }\end{array}$ & $\begin{array}{l}\text { Small (about } 8.52 \mathrm{~cm} \text { long } \times 4.75 \mathrm{~cm} \text { diameter) } \\
\text { (Biggest tuber harvested } 0.4 \mathrm{~kg} \text { ) }\end{array}$ \\
\hline Stolon & Tubers subtended in long stolon (about $100 \mathrm{~cm}$ ) & Stolon none, tubers clumped at stem base \\
\hline Anchor roots & With numerous spines & Sparse to nil \\
\hline
\end{tabular}

Table 2. General blade characteristics of the two varieties of Dioscorea esculenta and D. alata (outgroup)

\begin{tabular}{llll}
\hline \multirow{2}{*}{ Character } & $\begin{array}{l}\text { D. esculenta var. spinosa } \\
\text { Exsicc. Antonio 6893 (PBDH) }\end{array}$ & $\begin{array}{l}\text { D. esculenta var. fasciculata } \\
\text { Exsicc. Antonio 6894 (PBDH) }\end{array}$ & $\begin{array}{l}\text { D. alata (outgroup) } \\
\text { Exsicc. Antonio 6895 (PBDH) }\end{array}$ \\
\hline Pubescence & Both sides & Ventral side & None \\
Blade length (mm) & $74-105$ & $50-91$ & $117-173$ \\
& (Mean: 86) & (Mean: 72.833) & (Mean: 150.42) \\
Blade width (mm) & $86-140$ & $56-107$ & $87-164$ \\
& (Mean: 112.23$)$ & (Mean: 81.083$)$ & $6786-1891.83)$ \\
Blade area (mm2) & $4586.67-9800$ & $1866.67-6430.67$ & (Mean: 14398.28$)$ \\
& (Mean: 6465.31$)$ & (Mean: 4109.94$)$ & Majority mesophyll, few macrophyll \\
Blade class & Mesophyll & Notophyll & $1: 0.963-1: 1.345$ \\
Length-width ratio & $1: 0.615-1: 0.931$ & $1: 0.832-1: 0.956$ & $1: 1.078$ \\
& (Mean: $1: 0.773)$ & (Mean: $1: 0.902)$ & \\
\hline
\end{tabular}

Leaf architectural characteristics of Dioscorea esculenta var. spinosa and D. esculenta var. fasciculata

In terms of general blade characters, the two varieties of D. esculenta showed variability in all six characters examined (Table 2). The D. esculenta var. spinosa has pubescence on both ventral and dorsal sides, mesophyll blade class and is intermediate to $D$. esculenta var. fasciculata and D. alata (outgroup) in terms of blade length, width and area, and leaf-width ratio. The $D$. esculenta var. fasciculata, on the other hand, has pubescence on the ventral side, notophyll blade class and gave the smallest measurements in all blade size parameters. Comparing the outgroup D. alata, it is nonpubescent, generally mesophyll (although few samples were rated macrophyll), and had the biggest leaf blade measurements among the three taxa. There was no general leaf character shared by the two D. esculenta species. 
Table 3. General venation characteristics of the two varieties of Dioscorea esculenta and D. alata (outgroup)

\begin{tabular}{|c|c|c|c|}
\hline Character & $\begin{array}{l}\text { D. esculenta var spinosa } \\
\text { Exsicc. Antonio } 6893 \text { (PBDH) }\end{array}$ & $\begin{array}{l}\text { D. esculenta var fasciculata } \\
\text { Exsicc. Antonio } 6894 \text { (PBDH) }\end{array}$ & $\begin{array}{l}\text { D. alata } \\
\text { Exsicc. Antonio } 6895 \text { (PBDH) }\end{array}$ \\
\hline Primary vein category & Campylodromous & Campylodromous & Campylodromous \\
\hline \multirow{2}{*}{ No. of basal veins } & $9-10$ & $7-9$ & 7-9; majority \\
\hline & $\begin{array}{l}\text { One to two primary veins } \\
\text { distichously branching-numerous }\end{array}$ & $\begin{array}{l}\text { A primary vein distichously } \\
\text { branching-rare }\end{array}$ & $\begin{array}{l}\text { A primary vein distichously } \\
\text { branching-rare }\end{array}$ \\
\hline Primary vein size & Weak & Weak & Weak \\
\hline \multirow[t]{2}{*}{ Vein width $(\mathrm{cm})$} & $0.3-0.7$ & $0.4-0.5$ & $0.9-1.1$ \\
\hline & (Mean: 0.49) & (Mean: 0.508) & (Mean: 0.983) \\
\hline \multirow[t]{2}{*}{ Vein width/blade width } & $0.219-0.814$ & $0.476-1.11$ & $0.549-1.034$ \\
\hline & (Mean: 0.450 ) & (Mean: 0.662) & (Mean: 0.715 ) \\
\hline Primary vein course & Curved & Curved & Curved \\
\hline Secondary vein Category & Brochidodromous & Brochidodromous & Brochidodromous \\
\hline Secondary vein angle of divergence & Wide acute & Moderately acute & Moderately acute \\
\hline Secondary vein thickness & Moderate & Moderate & Fine \\
\hline Secondary vein course & Sinuous, branched & Sinuous, branched & Sinuous, branched \\
\hline Behavior of loop-forming branches & $\begin{array}{l}\text { Joining superadjacent secondary } \\
\text { at obtuse angle }\end{array}$ & $\begin{array}{l}\text { Joining superadjacent } \\
\text { secondary at obtuse angle }\end{array}$ & $\begin{array}{l}\text { Joining superadjacent secondary } \\
\text { at obtuse angle }\end{array}$ \\
\hline Secondary vein spacing & Irregular & Irregular & Irregular \\
\hline Intramarginal vein & Present & Present & Present \\
\hline Intersecondary vein & Present & Present & Present \\
\hline Tertiary vein course & Admedially ramified & Admedially ramified & Exmedially ramified \\
\hline Tertiary vein pattern & Random reticulate & Random reticulate & Random reticulate \\
\hline Tertiary vein angle to primary veins & Obtuse & Obtuse & Obtuse \\
\hline Quarternary vein category & Regular polygonal reticulate & Regular polygonal reticulate & Regular polygonal reticulate \\
\hline Pentanary vein category & Dichotomizing & Dichotomizing & Dichotomizing \\
\hline Areolation & Well developed & Well developed & Moderately developed \\
\hline Freely-ending veins & $\begin{array}{l}\text { 1-branched to } 2 \text { or more- } \\
\text { branched }\end{array}$ & $\begin{array}{l}\text { 1-branched to 2-or more } \\
\text { branched }\end{array}$ & $\begin{array}{l}\text { 1-branched to 2-or more } \\
\text { branched }\end{array}$ \\
\hline Highest order & 5 & 5 & 6 \\
\hline
\end{tabular}

The two varieties of $D$. esculenta are similar in majority (18 out of 22) of the venation characters observed (Table 3, Figure 3). They include campylodromous primary vein, weak primary vein size, curved primary vein course, brochidodromous secondary vein, sinuous and branched secondary vein course, loop-forming branches joining superadjacent secondary at obtuse angle, irregular secondary vein spacing, present intramarginal and intersecondary veins, random reticulate tertiary vein, obtuse tertiary-primary vein angle, regular polygonal reticulate quarternary vein, and 1-branched to 2-or more branched FEVS, among others. They differ in terms of the number of basal veins, vein width, vein width to blade width ratio and secondary vein angle of divergence.

The $D$. esculenta var. spinosa is so distinct from $D$. esculenta var. fasciculata and D. alata for having the highest number of basal veins (9-10) with very often occurrence of distichous branching in one or two of the primary veins nearest the blade margin (Table 3). It also has wide acute secondary vein angle of divergence in contrast to the moderately acute angle of divergence exhibited by the two other taxa.

Variation in the venation patterns of the two varieties is evident in the lower vein categories, particularly on the basal, primary and secondary veins. In contrast, variation in higher vein categories starting at the tertiary level is reported in Hoya by Tan and Buot (2018), and Torrefiel and Buot (2017).

In comparison with the outgroup D. alata, the two varieties exhibit greater variation from $D$. alata, differing in six out of 22 venation characters. Such variation is observed on the basal, secondary and tertiary veins and areolation. This observation corroborates the report of Hickey (1973) that there is high degree of interspecific variation on venation patterns, which is taxonomically important in distinguishing and identifying plant species from each other. 


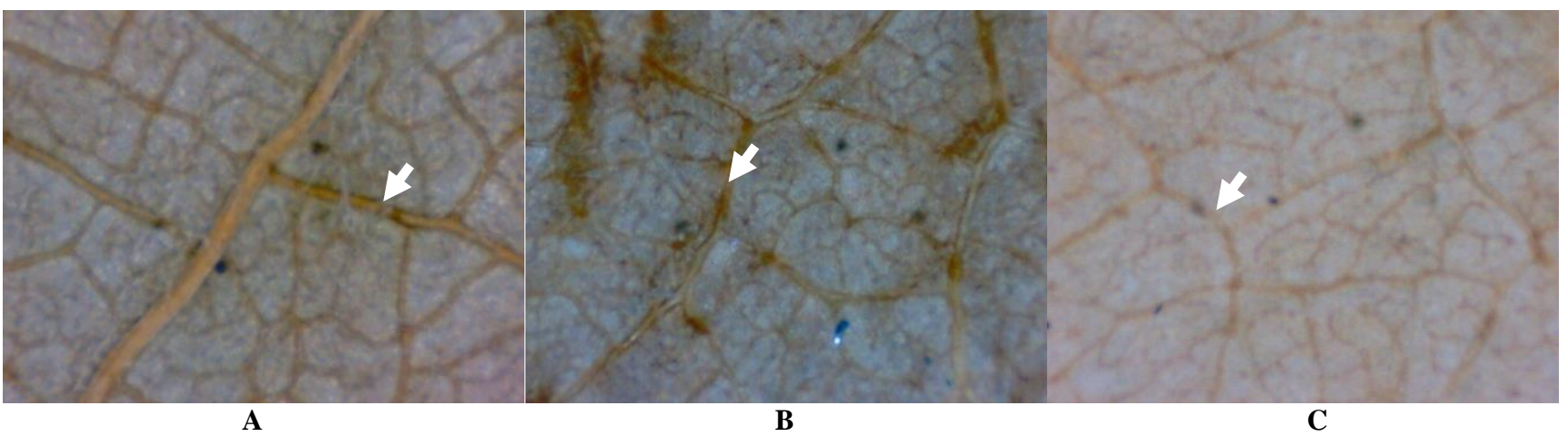

Figure 3. Leaf venation of Dioscorea esculenta var. spinosa (A), D. esculenta var. fasciculata (B), and D. alata, outgroup (C). Arrows pointing at secondary veins indicate moderate veins in A and B and fine veins in C. (Photo by M.A. Antonio)

\section{Key to the three Dioscorea taxa}

1a. Primary vein campylodromous, vein size weak, secondary vein brochidodromous, loop-forming branches at obuse angle with secondary vein

............................ 2

1b. Primary vein not campolydromous, vein size moderate to massive, Secondary vein not brochidodromous, loop-forming branches join at non-obtuse angle 4

2a. Secondary vein thickness moderate, tertiary vein admedially ramified, areolation well-developed .................... 3

2b. Secondary vein thickness fine to threadlike, tertiary vein exmedially ramified, areolation moderately developed D. alata

3a. Basal veins 9-10, one to two basal veins very often dischitously branched, secondary vein angle of divergence wide acute, blade class mesophyll

D. esculenta var. spinosa

3b. Basal veins $7-9$, one to two basal veins rarely dischitously branched, secondary vein angle of divergence moderately acute, blade class notophyl ..... D. esculenta var. fasciculata

Venation patterns are taxonomically important for interspecific delineation because their orientation and quantitative characters are relatively stable at the species level (Roth-Nebelsick et al. 2001; Fang et al. 2002; Buot 2020). Observed variations in the two varieties of $D$. esculenta also suggest that venation patterns could also be used as diagnostic tool for infraspecific delineation, although such variation is to a lesser extent. In addition, Sun et al. (2017) used venation patterns in delineating the different sections of genus Dioscorea. Together with morphology and chemical composition, venation patterns were used in restructuring the composition of the different sections of Dioscorea sampled in China.

\section{Descriptions of the leaf architecture characters of the Dioscorea esculenta varieties}

Dioscorea esculenta (Lour.) Burkill var. spinosa: Exsicc. Antonio 6893 (PBDH): Leaves pubescent on both sides; blade 74 to $105 \mathrm{~cm}$ long, 86 to $140 \mathrm{~cm}$ wide, mesophyll, 1:0.615 to 1:0.931 leaf length-width ratio; primary vein campylodromous, basal veins 9 to 10 , one to two basal veins very often distichously branched, primary vein size weak, course curved; secondary vein brochidodromous, angle of divergence wide acute, thickness moderate, sinuous, branched, loop-forming branches at obtuse angle with secondary vein, spacing irregular; intramarginal and intersecondary veins present; tertiary vein admedially ramified, random reticulate, angle obuse with primary vein; quarternary vein regular polygonal reticulate; pentanary vein dichotomizing; areolation well developed; free ending veins 1-branched to 2-or more-branched.

Dioscorea esculenta (Lour.) Burkill var. fasciculata: Exsicc. Antonio 6894 (PBDH): Leaves pubescent underside; blade 50 to $91 \mathrm{~cm}$ long, 56 to $107 \mathrm{~cm}$ wide, notophyll, 1:0.832 to 1:0.956 leaf length-width ratio; primary vein campylodromous, basal veins 7 to 9 , basal vein rarely distichously branched, primary vein size weak, course curved; secondary vein brochidodromous, angle of divergence moderately acute, thickness moderate, sinuous, branched, loop-forming branches at obtuse angle with secondary vein, spacing irregular; intramarginal and intersecondary veins present; tertiary vein admedially ramified, random reticulate, angle obtuse with primary vein; quarternary vein regular polygonal reticulate; pentanary vein dichotomizing; areolation well developed; free ending veins 1-branched to 2-or more-branched.

\section{Delineating the Dioscorea spp. using leaf architecture}

Cluster analysis using UPGMA (Figure 4) illustrated a distinction between the three taxa of Dioscorea. D. alata diverged from the two varieties of $D$. esculenta at a distance coefficient of 35 . Truncating the tree, the two $D$. esculenta varieties joined together earlier at a distance coefficient of 22 , thus indicating greater similarity with each other than with $D$. alata.

The divergence of the two $D$. esculenta varieties at a relatively lower distance coefficient (22) indicates lesser differences of the two taxa. Number of basal veins, distichous branching of primary veins, secondary vein angle of divergence, blade class and pubescence are distinguishing characters that separate the two D. esculenta varieties (Table 3). Data from leaf architecture and plant morphology confer current taxonomic treatment as distinct varieties of $D$. esculenta. 


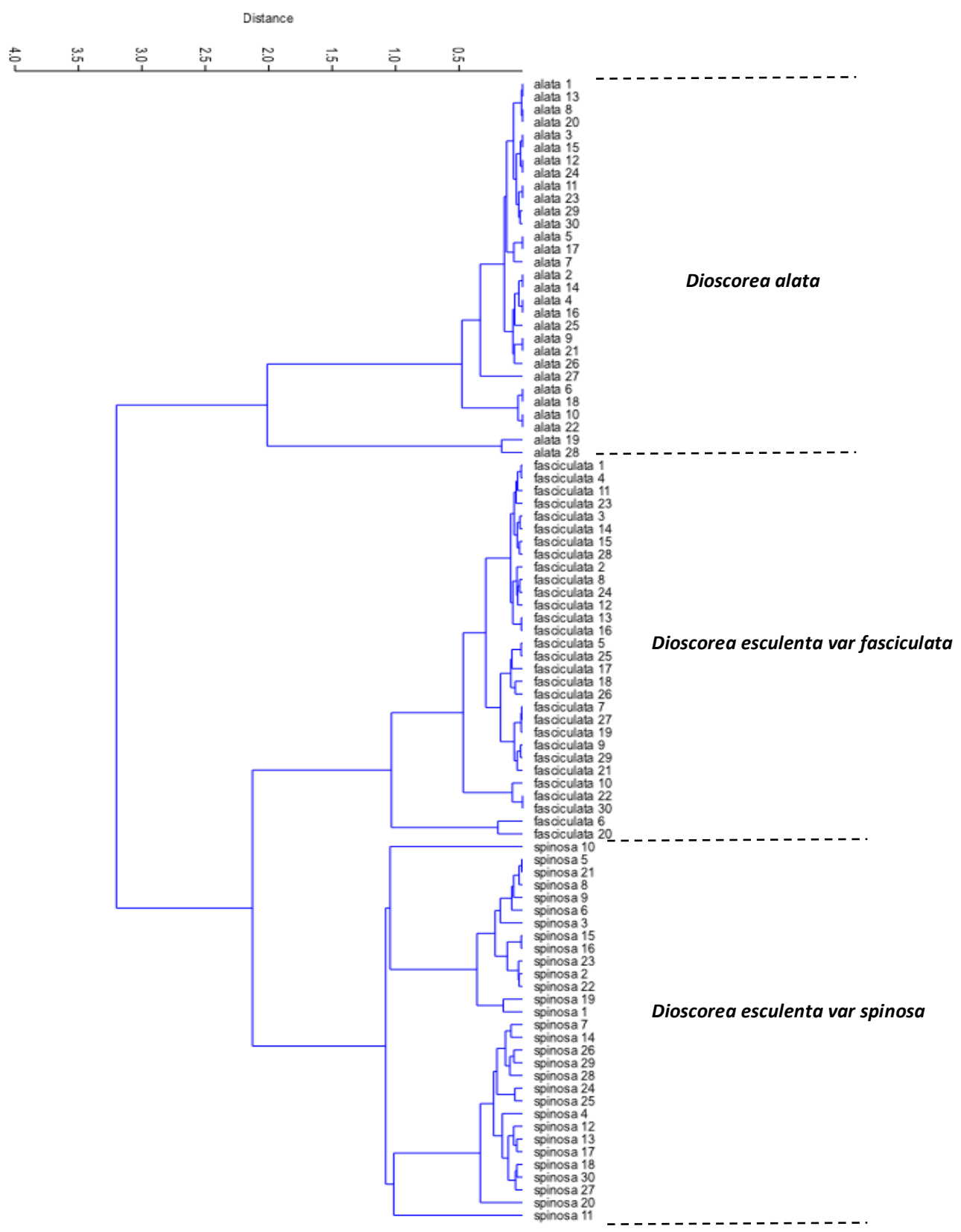

Figure 4. Unweighted pair-group average (UPGMA) clustering approach

However, the current name was given to $D$. esculenta var. fasciculata presents a contradiction to the rules of the International Code of Nomenclature for Cultivated Plants (ICNCP) (ISHS 2016). Since D. esculenta var. fasciculata is a cultivated variety, it should be treated under the ICNCP. So, following the ICNCP rules, a revision on the name of the cultivated variety is hereby proposed as: $D$. esculenta 'fasciculata'. D. esculenta var. fasciculata is now considered a synonym of $D$. esculenta 'fasciculata'. Meanwhile, the name of the wild variety remains as $D$. esculenta var. spinosa.

In the present study, leaf architecture is a useful tool for characterizing, delineating and classifying species. Results obtained from the analysis of $D$. esculenta and $D$. alata support their current species identity. Same approach was also helpful in delineating the infraspecific taxa of $D$. esculenta but to a lesser extent. A few venation characters, coupled with morphological characters, distinguish the two varieties of $D$. esculenta. Following the rules of ICNCP, $D$. esculenta var. fasciculata is proposed to be revised into $D$. esculenta 'fasciculata'. The name $D$. esculenta var. spinosa for the wild variety remains.

Further, it is recommended that studies using other approaches such as floral and petiole anatomy be conducted to supplement the present results. Molecular studies are likewise recommended to confirm morphological and anatomical observations. 


\section{ACKNOWLEDGEMENTS}

The authors would like to thank the Department of Science and Technology (DOST) for the scholarship grant, and the Crops Research Laboratory, Mariano Marcos State University (MMSU), Philippines for the free access to the laboratory equipment used in the conduct of the study.

\section{REFERENCES}

Antonio MA. 2008. Assessment of Genetic Diversity in, and Identification of Wild Dioscorea "Buga" through Morphological and Cytological Characterization. [Thesis]. University of the Philippines Los Baños, College, Laguna. [Philippines]

Baltazar AMP, Buot Jr. IE. 2019. Resolving taxonomic confusion between Hoya cumingiana Decne. and Hoya densifolia Turcz. (Apocynaceae) using leaf architectural analysis. Thai Nat Hist Mus J 13 (2): 77-89.

Banaticla MCN, Buot Jr. IE. 2004. Leaf architecture of ten Philippine Psychotria species (Fabaceae). Phillip Sci 41: 74-90.

Baroga J, Buot Jr. IE. 2004. Leaf architecture of ten species of Philippine Terminalia Linn. (Combretaceae). Intl Res J Biol Sci 3 (3): 83-88.

Buot Jr. IE. 2020. Leaf architecture as a promising tool in confirming identity of confusing plant taxa. J Nat Stud 19 (1): 134-143.

Caddick LR, Wilkin P, Rudall PJ, Hedderson TAJ, Chase MW. 2002. Yams reclassified: a recircumscription of Dioscoreaceae and Dioscoreales. Taxon 51 (1): 103-114. DOI: 10.2307/1554967

Fang Y, Liu J, Jiang Y. 2002. Characteristics and significance for the delimitation of species on the leaf venation of Chinese yam in Fujian. J Fujian Norm Univ Nat Sci Ed 18 (2): 65-69.

Hammer O, Harper DAT, Ryan PD. 2001. Past paleontological statistics software package for education and data analysis. Paleontol Elecronica 4 (1): 9.

Hickey LJ. 1973. Classification of the architecture of dicotyledonous leaves. Am J Bot 60 (1): 17-33. DOI: 10.1002/j.15372197.1973.tb10192.x

ISHS [International Society for Horticultural Science]. 2016. Internationa Code of Nomenclature for Cultivated Plants. 9th ed. Scripta Horticulturae Number 18. Drukkerij Station Drukwerk, Nederland https://www.ishs.org/sites/default/files/static/ScriptaHorticulturae_18. pdf.
Jumawan JH, Buot Jr. IE 2016. Numerical taxonomic analysis in leaf architectural traits of some Hoya R. Br. species (Apocynaceae) from Philippines. Bangladesh J Plant Taxon 23 (2): 199-207. DOI: 10.3329/bjpt.v23i2.30851

Laraño AA, Buot Jr. IE. 2010. Leaf architecture of selected species of Malvaceae sensu APG and its taxonomic significance. Philipp J Syst Biol 4: 21-54.

Leaf Architecture Working Group. 1999. Manual of leaf architecturemorphological description and categorization of dicotyledonous and net-veined monocotyledonous angiosperms. Smithsonian Institute, Washington DC.

Pelser PB, Barcelona JF, Nickrent DL (eds) 2011 onwards. Co's Digital Flora of the Philippines. www.philippineplants.org.

Prain D, Burkill IH. 1913. Dioscoreae Elmerianae. Leafl Philipp Bot 5 (78): 1589-1599.

Rao SRS, Rao SS. 2015. Leaf architectural studies in some Cucurbitaceae. J Indian Bot Soc 94 (1\&2) 2015: 64-72.

Raz L. 2016. Untangling the West Indian Dioscoreaceae: new combinations, lectotypification and synonymy. Phytotaxa 258 (1): 026-048. DOI: 10.11646/phytotaxa. 258.1.2.

Roth-Nebelsick A, Uhl D, Mosbrugger V, Kerp H. 2001. Evolution and function of leaf venation architecture: a review. Ann Bot 87 (5): 553 566. DOI: 10.1006/anbo.2001.1391

Salvaña F, Buot Jr. IE. 2014. Leaf architectural study of Hoya coriaceae, Hoya halconensis and Hoya buotii (Apocynaceae). Intl Res J Biol Sci 3 (3): 37-44.

Sun XQ, Xue JY, Lei Z, Zhang YM, Li MM, Zhou GC, Hang Y. 2017. Taxonomic and phylogenetic significance of leaf venation characteristics in Dioscorea plants. Arch Biol Sci 70 (2): 58-58. DOI: 10.2298/ABS170322058S

Tan JMP, Buot Jr. IE. 2018. Delineating two species Hoya benguetensis Schltr. and Hoya ilagiorum Kloppenb., Siar \& Cajano (Apocynaceae): a leaf architectural approach. Thai Nat Hist Mus J 12 (2): 103-109.

Torrefiel J, Buot Jr. IE. 2017. Hoya carandangiana, Hoya bicolensis and Hoya camphorifolia (Apocynaceae) species delineation: insights from leaf architecture. Thai Nat Hist Mus J 11 (1): 35-41.

Villareal AMM, Buot Jr. IE. 2015. Leaf architecture of Hoya incrassata Warb., and Hoya crassicaulis Elmer x Kloppenb. (Apocynaceae) taxonomic identification and conservation concerns. IAMURE Intl J Ecol Conserv 15 (1): 203-213. DOI: 10-7718/ijec.v15i1.1002. 